\title{
Propolis for the control of powdery mildew and the induction of phytoalexins in cucumber
}

\author{
El propóleo para el control de oídio y la inducción de fitoalexinas en pepino \\ Claudia Aparecida Guginski-Piva1, Idalmir dos Santos ${ }^{2 *}$, Américo Wagner Júnior ${ }^{3}$, \\ Daniel Winter Heck ${ }^{4}$, Mariana Faber Flores ${ }^{5}$, Kelly Pazolini ${ }^{2}$
}

\begin{abstract}
Due to its antimicrobial properties propolis has been utilised by man for millennia, however, only recently has its use as an agricultural antimicrobial agent been tested. The capacity of this product to activate plant defence mechanisms is highly promising, due to the large number of substances in its composition. Therefore, the objective of this study was to evaluate the effect of different concentrations and application times of ethanol extracts of propolis (EEP) on powdery mildew (Podosphaera fuliginea) in cucumber crops, to establish the most suitable method for control and whether or not there is potential to induce plant defence mechanisms. The experiment was conducted in pots in a greenhouse. A completely randomised experimental design was employed, using a $6 \times 3$ factorial consisting of six concentrations $(0 ; 0.5 ; 1 ; 2 ; 4$ and 8\%) and three EEP application times (24 hours before pathogen inoculation, 24 hours after pathogen inoculation and at the onset of first symptoms of the disease), replicated four times. Evaluations for disease incidence and severity were made weekly. The experiment was repeated for a second crop, following the same methodology established in the first. We also evaluated the effect of different EEP concentrations on the activation of plant defence mechanisms, through the induction of phytoalexins in soybean (Glycine max) cotyledons. A significant interaction was observed between the factors (application time x concentration) for disease incidence. For the area under the disease progress curve (AUDPC) for severity there was no interaction observed between the factors, however, we observed significant differences for the two factors separately. The AUDPC for incidence was less for the application 24 hours after pathogen inoculation, principally at the highest concentration. The $8 \%$ concentration of EEP controlled disease severity by 31.33 and $43.68 \%$ for the first and second crops, respectively. The application of the concentrations 24 hours before and 24 hours after pathogen inoculation showed less AUDPC for severity, but this difference was not significant for either crop. The EEP induced increasing phytoalexin levels in soybean cotyledons as the applied EEP concentration increased. Ethanol extracts of propolis could have potential for the control of powdery mildew, principally in cucumbers, through the preventive application of an $8 \%$ concentration.
\end{abstract}

Key words: Podosphaera fuliginea, alternative control, ethanol extract of propolis, cucumber

\section{RESUMEN}

Debido a sus propiedades antimicrobianas el propóleo ha sido utilizado por el hombre desde hace milenios, sin embargo solo recientemente se ha probado como un agente antimicrobiano agrícola. Además, la capacidad de este producto para activar los mecanismos de defensa de la planta es muy prometedor, debido a la gran cantidad de sustancias en su composición. Por tanto, el objetivo de este estudio fue evaluar el efecto de diferentes concentraciones y tiempos de aplicación de los extractos etanólicos de propóleos (EEP) en el oídio (Podosphaera fuliginea) en cultivos de pepino, para establecer el método más adecuado para el control y la existencia o no de este potencial para inducir los mecanismos de defensa de la planta. El experimento se llevó a cabo en macetas en un invernadero. Fue empleado un diseño experimental completamente al azar, utilizando un factorial $6 x 3$, que consiste en seis concentraciones $(0 ; 0,5 ; 1 ; 2 ; 4$ y 8\%) y tres momentos de aplicación EEP (24 horas antes de la inoculación del patógeno, 24 horas después de la inoculación de patógenos y en la aparición de los primeros síntomas de la enfermedad) con

1 Universidade do Estado de Santa Catarina - Campus Lages. Centro de Ciências Agroveterinárias Av Luiz de Camões, 2090, Lages, SC, Brasil.

2 Universidade Tecnológica Federal do Paraná - Campus Pato Branco, Via do Conhecimento, Km 1, Pato Branco, PR, Brasil.

3 Universidade Tecnológica Federal do Paraná - Campus Dois Vizinhos, Estrada para Boa Esperança, Km 04, Dois Vizinhos, PR, Brasil.

4 Universidade Estadual Paulista Júlio de Mesquita Filho - Campus Botucatu, Distrito de Rubião Júnior, s/nº, Botucatu, SP, Brasil.

5 Universidade Federal do Paraná - Campus Curitiba. R. dos Funcionários, 1540 - Cabral, Curitiba, PR, Brasil.

* Corresponding author: idalmir@utfpr.edu.br

Fecha de Recepción: 7 Julio, 2014.

Fecha de Aceptación: 1 Diciembre, 2014. 
cuatro repeticiones. Las evaluaciones para la incidencia y gravedad de la enfermedad se realizaron semanalmente. El experimento se repite para más de un cultivo, siguiendo la misma metodología establecida en la primera. También se evaluó el efecto de diferentes concentraciones de EEP en la activación de los mecanismos de defensa de la planta, mediante la inducción de fitoalexinas en la soja (Glycine max), cotiledones. Se observó una interacción significativa entre los factores de concentración (x tiempo de aplicación) para la incidencia de la enfermedad. Para el área bajo la curva de progreso de la enfermedad $(A U D P C)$ para la gravedad no hubo interacción observada entre los factores, sin embargo, se observaron diferencias significativas para los dos factores por separado. El AUDPC para la incidencia fue menor para la aplicación 24 horas después de la inoculación de patógenos a la mayor concentración. El EEP inducida aumentó los niveles de fitoalexina en cotiledones de frijol de soya según la concentración aplicada. Los extractos etanólicos de propóleos podrían tener potencial para el control del mildiu pulverulento, principalmente en los pepinos, por medio de la aplicación preventiva de una concentración al 8\%.

Palabras clave: Fuliginea podosphaera, control alternativo, extracto etanólico de propóleos, pepino.

\section{Introduction}

The cucumber (Cucumis sativus L.) is susceptible to several diseases which cause reduced production, loss in the economic value of the fruit and increase in the cost of production. Powdery mildew, caused by Podosphaera fuliginea (Schltdl.) U. Braun \& S. Takam (2000), is the principal fungal disease of this crop, especially when produced under protected cultivation where it can cause severe damage (STADNIK, 2000).

Control of powdery mildew can be achieved through the use of resistant cultivars, fungicide application and crop rotation among others (STADNIK et al., 2001). The use of resistant cultivars is not obtained with ease, as the resistance is controlled by a dominant gene $\mathrm{R}$ that is only expressed in the presence of the recessive gene $\mathrm{s}$. Furthermore, there is also a gene inhibitor I that impedes the expression of complete resistance (Bedendo, 1995).

The use of fungicides is the method most commonly implemented that presents satisfactory levels of control. Initially, fungicides based on sulphur were the most commonly utilised, however, they are no longer the most recommended due to the appearance of phytotoxicity (Stadnik et al., 2001). The development of systemic fungicides has overcome this problem, however, these present a higher risk of resistance, since their efficacy is temporary and they possess specific modes of action and action sites. Fungicides applied at high dose and frequency increase the selection pressure, and consequently induce the emergence of resistant individuals in addition to contaminating the agroecosystem.

The use of alternative control methods that are efficient, have low potential for environmental contamination and do not cause damage to the health of the applicator have been the subject of various studies, such as those conducted by Bettiol et al. (1999), Carneiro et al. (2007) and Faria et al. (2011), among others. These alternative control methods are normally based on obtaining the extract of a specific plant or product that shows capacity for inhibiting infection. Among the possible usable materials are extracts of propolis, as they have a high potential to possess antimicrobial, antifungal, antioxidant, antiviral and antiprotozoal activity (Pereira et al., 2008). The composition of propolis can vary according to the species of bee and the time of year in which it was collected, with more than 300 substances being recorded as propolis constituents (Bankova, 2005).

Studies have been conducted with propolis, used by bees as a defence against microorganisms, particularly in the area of veterinary medicine. The effective use of propolis extract in agriculture has been demonstrated through the control of bacteria in vitro (Grange and Davey, 1990). Basim et al. (2006) determined the antibacterial activity of Turkish propolis against 13 bacterial phytopathogens: $A$. tumefaciens, A. vitis, C. michiganensis, E. amylovora, E. carotovora, Pseudomonas corrugata, P. savastanoi, $P$. syringae (4 strains), Ralstonia solanaceraum, $X$. campestris and $X$. axonopodis, after they all showed sensitivity to this extract. Nevertheless, little is known about the effect of propolis on fungal phytopathogens. Few studies have been conducted, the majority of which have been performed under laboratory conditions, without proof of applicability in the field. Therefore, propolis could be tested for the control of powdery mildew in cucumber.

The objective of this study was to evaluate the efficiency of different concentrations and application times of ethanol extractions of propolis for controlling powdery mildew in cucumber under protective 
cultivation, and its potential for the inducing plant defence mechanisms.

\section{Material and Methods}

The experiment was conducted at the Federal Technologic University of Paraná, Pato Branco Campus-PR, at latitude 26 $10^{\circ} 38^{\prime \prime}$ S and longitude $52^{\circ} 41^{\prime} 24^{\prime \prime} \mathrm{W}$, at 764 metres altitude, from October 2011 to March 2012.

\section{Preparation of the Ethanol Extract of Propolis}

The propolis used in the experiment was collected from Apis mellifera from the city of Pato Branco (PR), Brazil. The propolis was frozen, ground to a fine powder and mixed with ethanol $70^{\circ} \mathrm{GL}$, in the proportion $30 \%$ crude propolis to $70 \%$ ethanol. The mixture was stored in dark glass vials, which were closed and kept at room temperature in a secure place for two months; they were shaken daily. At the end of this period the extract was separated from the sediment using filter paper. The concentration obtained was considered as $100 \%$ and from this the other concentrations were created by dilution with distilled water.

\section{Effect of Ethanol Extracts of Propolis on Powdery Mildew}

The experiment was conducted under ambient conditions inside a greenhouse, which was an environment free of the disease pathogen inoculum. The cucumber seedlings, cultivar 'Caipira', were grown in the cells of polystyrene trays containing the commercial substrate Plantmax. Two weeks after planting, 8 cucumber seedlings were transplanted into $7.0 \mathrm{~L}$ pots containing forest soil, which had been adjusted for the needs of the culture according to ROLAS (2004). Thinning was performed three weeks after the sowing was conducted, leaving only four plants per pot.

Application of the treatments was performed manually using a sprayer with a conical nozzle until the leaves were completely wetted. A completely randomised experimental design was employed, using a $3 \times 6$ factorial (application time $\mathrm{x}$ extract concentration), with 4 replicates each consisting of a pot containing 4 plants. The three levels of the factor 'application time' were 24 hours before pathogen inoculation, 24 hours after pathogen inoculation and at the onset of disease symptoms; the six concentrations of the extract tested were 0 ; $0.5 ; 1 ; 2 ; 4$ and $8 \%$. For $0 \%$ concentration distilled water was sprayed. Dilutions of the ethanol extract of propolis (EEP) were prepared in the morning of each application day. After the first EEP application a new spray was made every 7 days for five consecutive weeks. Drip irrigation of the soil was utilised during the crop cycle to maintain field capacity.

Pathogen inoculation was performed by shaking leaves with symptoms of powdery mildew onto the plants. A high potential for pathogen inoculation was maintained at the experiment site using ten pots containing four cucumber plants with high disease severity arranged between the experimental units, whose position was alternated at intervals of three days. The experiment was repeated for a second crop, following the same methodology established for the first crop.

\section{Evaluation of Disease Incidence and Severity}

The evaluations of disease incidence and severity were made weekly; the first was performed as soon as the first symptoms of the disease emerged. Subsequent evaluations were made preceding each application of the EEP, totalling five evaluations. To evaluate the incidence of the powdery mildew all of the leaves of the plants comprising the experimental units were evaluated, noting the presence or absence of disease symptoms and signs of the pathogen on the leaves.

The evaluation of disease severity was based on the diagrammatic scale for powdery mildew in cucurbits (Azevedo and Leite 1996). For this the leaves of the lower and middle thirds of the plants were evaluated. After obtaining the incidence and severity results, the area under the disease progress curve (AUDPC) was calculated as described by Shaner and Finney (1977).

\section{Propolis extracts on the induction of phytoalexins in soya bean cotyledons}

The concentrations tested were: $0 \%$ (water); $0.5 ; 1 ; 2 ; 4$ and $8 \%$ propolis extract. Soybean seeds of the cultivar BMX Apollo were sown in trays containing the substrate Plantmax and maintained in a glasshouse. After ten days cotyledons were removed from the seedlings and washed in distilled water. Following this cuts were made at the abaxial base, approximately $1 \mathrm{~mm}$ deep and $6 \mathrm{~mm}$ in diameter 
and on this cut $50 \mu \mathrm{L}$ of the elicitor solution ( $0 \%$ (water), $0.5 ; 1 ; 2 ; 4$ and $8 \%$ propolis extract) was deposited. Five cotyledons were placed in Petri dishes which contained filter paper dampened with sterile distilled water. The Petri dishes were maintained at $25{ }^{\circ} \mathrm{C}$ for 20 hours in the dark in B.O.D. (Biochemical Oxygen Demand). After the period of incubation the cotyledons were transferred to test tubes containing $10 \mathrm{ml}$ sterile distilled water and agitates for 1 hour to extract the phytoalexin glyceollin. The absorbance was determined using a spectrophotometer at a wavelength of $285 \mathrm{~nm}$.

\section{Analysis of the data}

The data obtained in the experiments were subjected to analysis of variance, when a significant interaction was observed between the factors (application time $\mathrm{x}$ extract concentration), or for each one in isolation, the means were submitted individually to regression using $5 \%$ probability of type I error by an F-test. The analyses were performed using the statistical software R (2010).

\section{Results and Discussion}

The areas under the disease incidence progress curve (AUDIPC) calculated for the first and second crops showed significant interaction $(\mathrm{P} \leq 0.05)$ between the two factors studied (application time $\mathrm{x}$ extract concentration). For the first crop the EEP reduced the incidence of powdery mildew in cucumber, except for the $1 \%$ concentration at the application period 24 hours before inoculation and at the onset of symptoms, and for the $0.5 \%$ concentration applied at the onset of symptoms (Figure 1).

The lowest incidence for all the application times was observed for the $8 \%$ EEP concentration, which gave a control level of 18, 31 and $22 \%$ for the applications 24 hours before inoculation, 24 hours after inoculation and at the onset of symptoms, respectively. For the three application times, increasing concentrations of EEP elicited a decreasing linear trend with $\mathrm{r}^{2}=0.70 ; \mathrm{r}^{2}=0.81$ and $\mathrm{r}^{2}=0.65$, respectively. The highest values of disease incidence were observed for the application following the onset of symptoms, for all the concentrations except the $8 \%$ concentration,

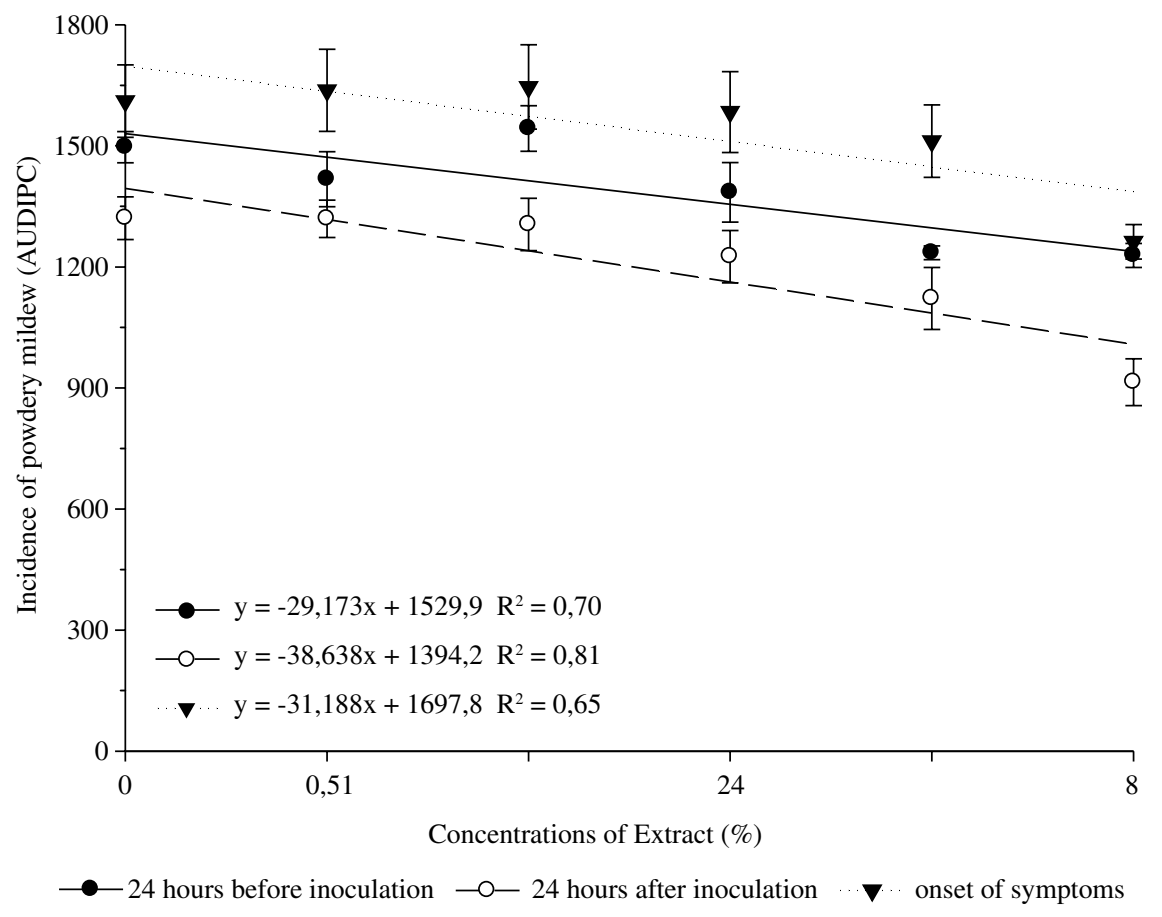

Figure 1. Incidence of powdery mildew, Podosphaera fuliginea, dependent on the application of increasing concentrations of ethanol extract of propolis $(0 ; 0.5 ; 1 ; 2 ; 4$ and $8 \%$ ), for three application times (24 hours before pathogen inoculation, 24 hours after pathogen inoculation and at the onset of disease symptoms), expressed by the area under the disease incidence progress curve (AUDIPC). First crop. UTFPR, Pato Branco -PR, 2011. 
which did not differ from the application made 24 hours after pathogen inoculation (Figure 1).

For the second crop the incidence showed lower AUDIPC values for all evaluation times compared to the first crop, with a decreasing linear tendency for the three application times, with $\mathrm{r}^{2}=0.86 ; \mathrm{r}^{2}$ $=0.85$ and $\mathrm{r}^{2}=082$ for the applications 24 hours before inoculation, 24 hours after inoculation and at the onset of symptoms, respectively (Figure 2). Powdery mildew incidence was greater when the application of EEP was made at the onset of symptoms compared to the respective EEP concentrations of the other application times, with the exception of the $2 \%$ concentration applied 24 hours before pathogen inoculation (Figure 2).

In the application 24 hours after inoculation the concentrations 2, 4 and $8 \%$ caused reductions in the AUDIPC of 37, 29 and 56\%, respectively. The $8 \%$ concentration also performed well when the EEP was applied at the onset of symptoms, giving a percentage of control of disease incidence of $37 \%$, compared to the control and 24 hours before inoculation, which had a control level of $33 \%$.
The AUDPC results for powdery mildew severity in cucumbers showed no significant interaction between the factors extract concentration and application time, for both the first and second crops (Figures 3 and 4 and Table 1). Significance was observed only for the two factors separately.

For the first crop there were no major variations in the reduction of AUDSPC due to an increase in the concentration of the extract, but showed a decreasing linear relationship, $\mathrm{r}^{2}=0.82$ (Figure 3 ). The concentrations $0.5,1$ and $2 \%$ did not control the disease, which was similar to the results found by Vieira \& Andrade, (2009), who, evaluating the propolis extracts of 0.8 and $1.6 \%$ for the control of powdery mildew in cucumber, observed results statistically equal to the control (water), with a reduction in severity of $4 \%$ and control through the application of a higher concentration, $8 \%$, which showed an average of $31 \%$.

For the second crop the area under the disease severity progress curve (AUDSPC) reduced with increasing concentration, showing a linear behaviour, with $\mathrm{r}^{2}=0.93$ (Figure 4). In this crop the disease

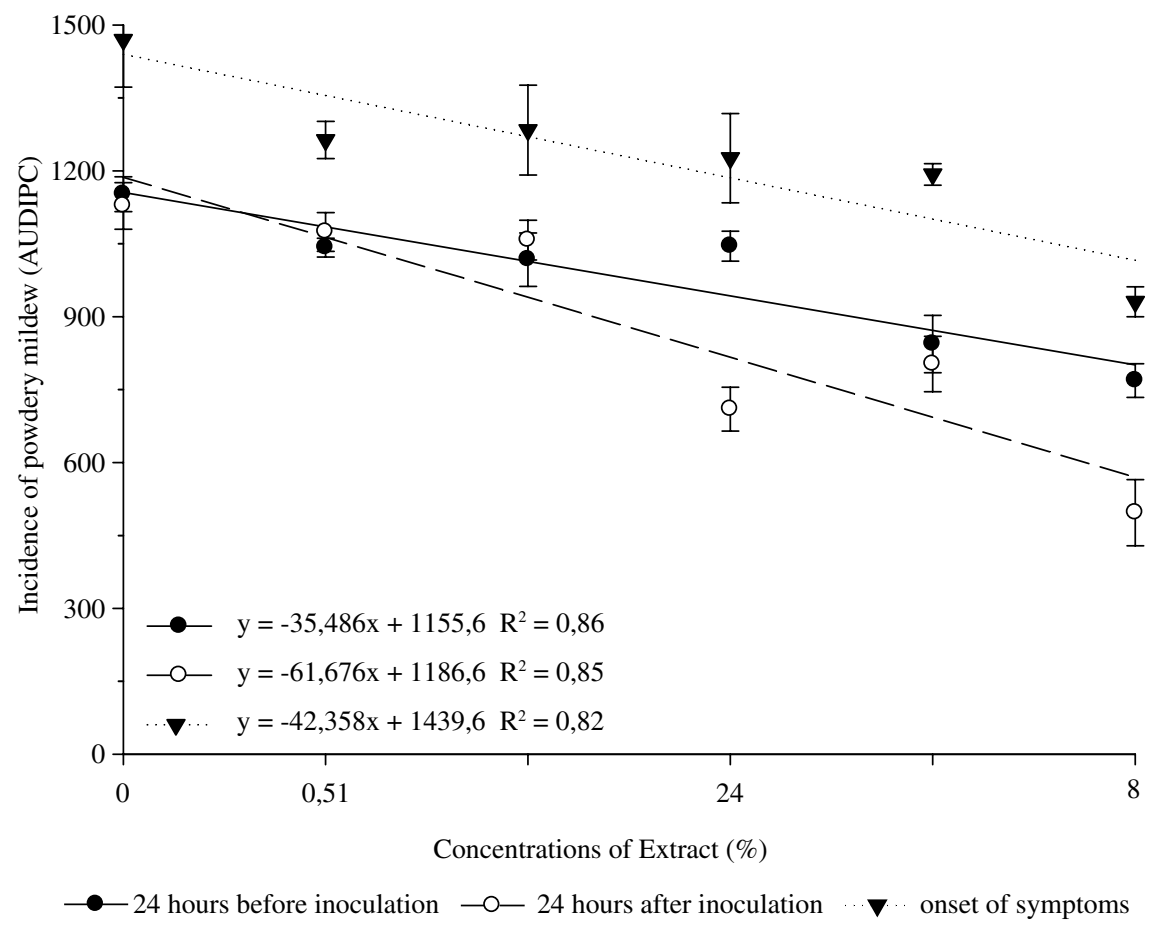

Figure 2. Incidence of powdery mildew, Podosphaera fuliginea, dependent on the application of increasing concentrations of ethanol extract of propolis $(0 ; 0.5 ; 1 ; 2 ; 4$ and 8\%), for three application times (24 hours before pathogen inoculation, 24 hours after pathogen inoculation and at the onset of disease symptoms), expressed by the area under the disease incidence progress curve (AUDIPC). Second crop. UTFPR, Pato Branco-PR, 2012. 


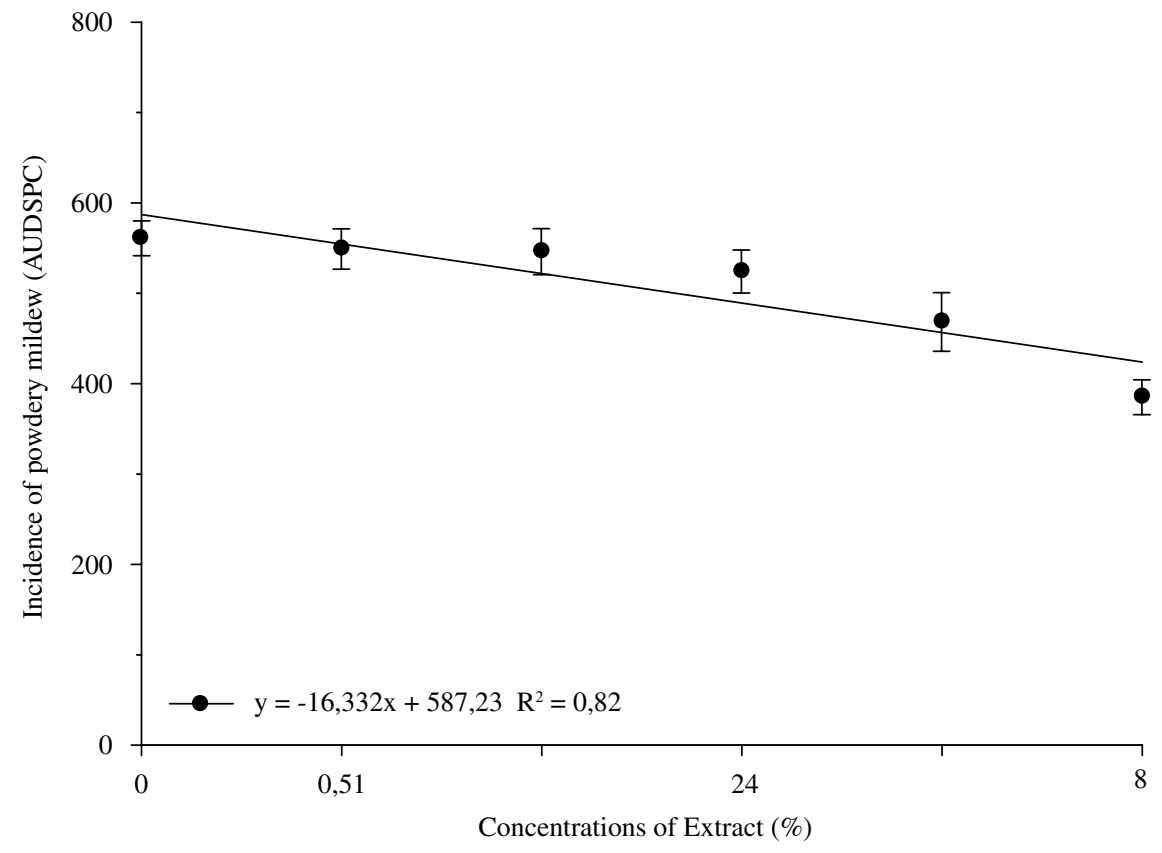

Figure 3. Severity of powdery mildew, Podosphaera fuliginea, dependent on the application of increasing concentrations of ethanol extract of propolis $(0 ; 0.5 ; 1 ; 2 ; 4$ and $8 \%)$, expressed by the area under the disease severity progress curve (AUDSPC). First crop. UTFPR, Pato Branco-PR, 2011.

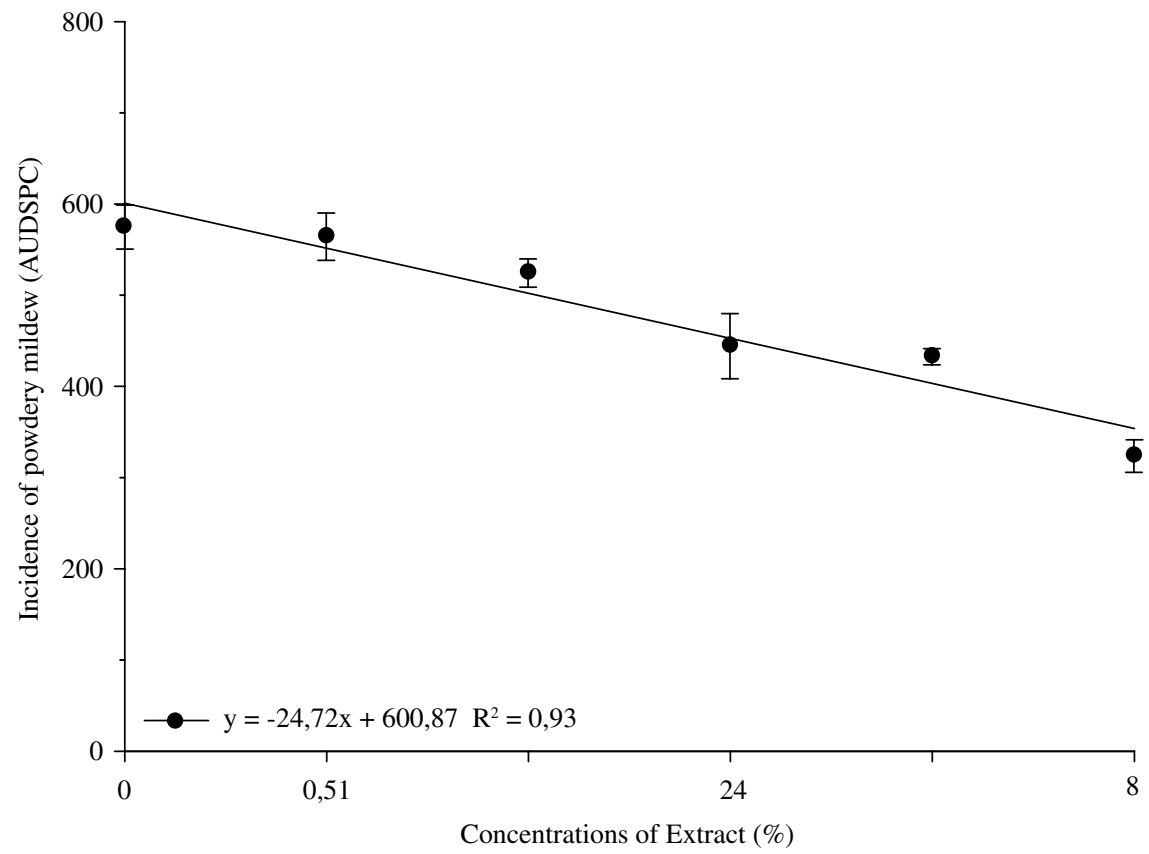

Figure 4. Severity of powdery mildew, Podosphaera fuliginea, dependent on the application of increasing concentrations of ethanol extract of propolis $(0 ; 0.5 ; 1 ; 2 ; 4$ and $8 \%)$, expressed by the area under the disease severity progress curve (AUDSPC). Second crop. UTFPR, Pato Branco -PR, 2012. 
control occurred from the $2 \%$ concentration with a mean of $23 \%$; the concentration $4 \%$ provided a similar level of control, $25 \%$, which confirms the previous results in which the concentration of $8 \%$ was found most effective at reducing the disease, with control of $43 \%$.

Compared to other alternative methods for powdery mildew control in cucumber, such as the use of milk (Bettiol et al., 1999), plant extracts (Konstantinidou-Doltsinis and Schmitt, 1998; Faria et al., 2011) or aqueous extracts of organic material (Ishida et al., 2001) the control obtained by EEP even at the concentration of $8 \%$ can be considered low. However, considering that all the conditions were favourable for the disease to occur at high intensity, the efficiency of the EEP means that it could be indicated for the integrated management of the disease under real production conditions. Thus if EEP is available at a property it could be used as another alternative method for the management of this disease.

Another factor to be considered is the variation of microbial activity of propolis on the time of collection and the local seasonality. In a preliminary study (unpublished data) conducted by the authors to control powdery mildew on cucumber, higher disease control was obtained in the present study. This difference in control when working with propolis collected from different regions or in different seasons was studied by Castro et al., (2007), who concluded that, over the periods studied, seasonality influenced the antibacterial activity due likely to change in the concentration of bioactive compounds derived from plant sources such propolis.

For the different EEP application times a significant difference was also observed in AUDPC for severity in both crops. For the first crop the extract application at the onset of symptoms showed the highest AUDPC, differing significantly from that of the application 24 hours after pathogen inoculation which presented the lowest AUDPC, while the extract application 24 hours before inoculation did not differ from the other two application times (Table 1).

For the second crop, as in the first, the application times that showed the lowest AUDPC for severity were 24 hours after inoculation and 24 hours before pathogen inoculation. These two application times did not differ significantly from each other, however, they differed from application at the onset of symptoms. These results suggest that to obtain the best control efficiency of powdery mildew in cucumbers using EEP it must be applied preventatively.
Table 1. Severity of powdery mildew, Podosphaera fuliginea, dependent on the application of increasing concentrations of ethanol extracts of propolis in cucumbers, expressed by the area under the disease severity progress curve (AUDSPC). First and second crop. UTFPR, Pato Branco-PR, 2011 and 2012.

\begin{tabular}{lcc}
\hline \multirow{2}{*}{ Application time } & \multicolumn{2}{c}{ Severity (AUDSPC) } \\
\cline { 2 - 3 } & First crop & Second crop \\
\hline 24 hours before inoculation & $496.20 \mathrm{ab}$ & $468.37 \mathrm{a}$ \\
24 hours after inoculation & $447.14 \mathrm{a}$ & $318.87 \mathrm{a}$ \\
Onset of symptoms & $561.66 \mathrm{~b}$ & $647.85 \mathrm{~b}$ \\
C.V. $(\%)$ & 14.27 & 21.04 \\
\hline
\end{tabular}

Means followed by the same letter in a column do not differ significantly by the Tukey test $(\mathrm{P} \leq 0.05)$.

The results obtained when the application time was 24 hours before inoculation could be related to the formation of a protective layer that prevents the penetration of the fungus, promoting an environment more favourable for the leaves to resist infection by the pathogen, and in addition allowing the accumulation of antifungal substances in the cuticle (Pozza et al., 2004). On the other hand, the results obtained with the application 24 hours after pathogen inoculation suggest that its effect is related to spore germination, and could also have a direct effect on the establishment of the pathogen in the plant tissue, due to the performance of the EEP on the fungal structures, principally during the infection phase.

The presence of phenolic compounds, especially flavonoids and phenolic acids, which together with modified carboxylic acids are the constituents of propolis responsible for bioactivity against various pathogenic microorganisms (Burdock, 1998), varies from one location to another. Thus extracts originating from different locations have a different action upon each pathosystem, as already established by other studies (Garedew et al., 2004; Uzel et al., 2005). The results obtained demonstrate that these compounds present in the EEP utilised were probably not sufficient to control the disease by over $50 \%$ at the concentrations used in this study.

Given that there was no significant difference in the severity of the disease for both crops when the extract was applied 24 hours before and after pathogen inoculation it is possible that resistance induction took place, since the propolis extract induced the production of phytoalexin glyceollin in soybean cotyledons (Glycine max), at the same concentrations tested, responding progressively with increasing dose (Figure 5). Phytoalexins are antimicrobial secondary 


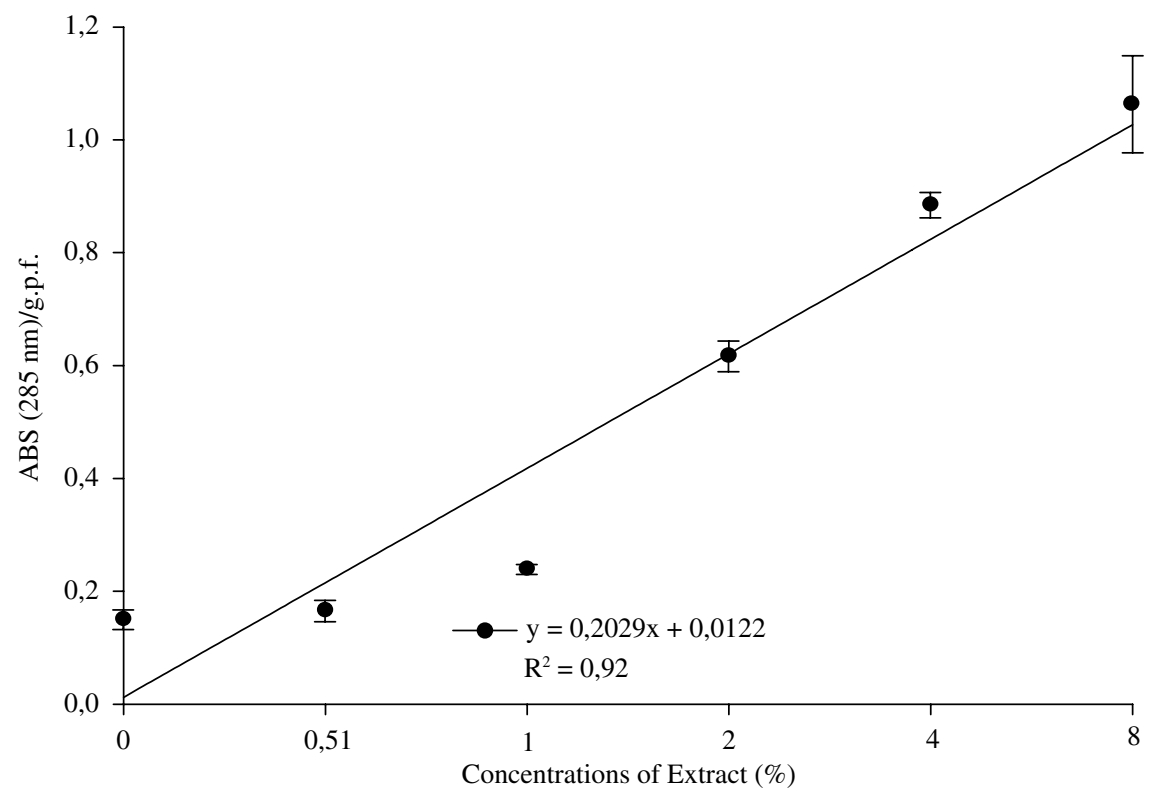

Figure 5. Induction of phytoalexins in soya bean cotyledons in response to doses of non-alcoholic extracts of propolis $(0 ; 0.5 ; 1$; 2; 4 and 8\%). UTFPR, Pato Branco -PR, 2011.

metabolites, produced by plants in response to some types of stress. Their mode of action on fungi includes cytoplasmic granulation, disorganisation of the cell contents, disruption of the plasma membrane and inhibition of fungal enzymes, which result in the inhibition of germination, elongation of the germination tube and in the reduction or inhibition of mycelial growth (Cavalcanti et al., 2005).

It is possible that by increasing the concentration of the propolis extract used a greater level of disease control could be obtained, as in Moraes et al. (2011) who tested a 10\% concentration of propolis extract for control of powdery mildew in tomato plants. In that study they found greater efficiency compared to the fungicide Tebuconazole. Similarly Stompor-Chrzan (2004), treating bean seeds with concentrations of 4 and 10\% EEP for the control of pathogens that cause damping-off, found that $10 \%$ was more efficient at inhibiting fungal infections, resulting in visually healthy plants.

Through the constant presence of untreated plants contaminated with disease inoculum and through the use of protected cultivation which enhances the colonisation of the pathogen, the development of the disease was rapid. In the second week of evaluation the control treatment showed a mean severity level of more than $80 \%$. However, the control of this disease $(43 \%)$ obtained through the application of the $8 \%$ concentration of EEP was higher than that obtained by neem oil and Azoxistrobin in a study conducted by Faria et al. (2011), which showed 36.8\% and $27.8 \%$ final control efficiency, respectively, in Japanese cucumbers under protective cultivation.

Future studies should be conducted aiming to evaluate the potential of the compounds contained in EEP and their effect on the activation of plant defence mechanisms.

\section{Conclusion}

The level of control provided by the EEP observed under these study conditions showed its effectiveness as an alternative control product for reducing powdery mildew in cucumber cultivated in a protective environment, when applied preventively.

The propolis extract was capable of inducing phytoalexin glyceollin in soybean cotyledons, responding proportionately to an increase in the dose, demonstrating its potential for the activation of plant defence mechanisms.

\section{Acknowledgements}

The authors thank the Program for Research Support UTFPR - Campus Pato Branco, Brazil, for financial support. 


\section{Literature Cited}

Azevedo, L.A.S. de; Leite, O.M.C. 1996. Manual de Quantificação de doenças de plantas. Ciba Agro. São Paulo, SP, 73 p.

Bankova, V.

2005. Chemical diversity of propolis and the problem of standardization. Journal of Ethnopharmacology, 100: 114-117.

Basim, E.; Basim, H.; Özcan, M.

2006. Antibacterial activities of Turkish pollen and propolis extracts against plant bacterial pathogens. Journal of Food Engineering, 77: 992-996.

Bedendo, I.P.

1995. Oídios. In: bergamin filho, A.; Kimati, H.; Amorim, L. Manual de Fitopatologia - Volume 1: Princípios e Conceitos. ed. Agronômica Ceres, São Paulo-SP., pp. 473-477.

Bettiol, W.

1999. Effectiveness of cow's milk against zucchini squash powder y mildew (Sphaerotheca fuliginea) in greenhouse con-ditions. Crop Protection, 18: 489-492.

Burdock, G.A.

1998. Review of the biological properties and toxicity of bee propolis. Food and Chemical Toxicology, 36: 347-363.

Carneiro, S.M. de T.P.G.; Pignoni, E.; Vasconcellos, M.E. da

C.; Gomes, J.C.

2007. Eficácia de extratos de nim para o controle do oídio do feijoeiro. Summa Phytopathologica, 33: 34-39.

Castro, M.L.; Cury, J.A.; Rosalen, P.L.

2007. Própolis do sudeste e nordeste do Brasil: influência da sazonalidade na atividade antibacteriana e composição fenólica. Química Nova, 30: 1512-1516.

Cavalcanti, L.S.; Brunelli, K.R.; Stangarlin, J.R.

2005. Aspectos bioquímicos e moleculares da resistência induzida. In: Cavalcanti, L.S.; Di piero, R.M.; Cia, P.; Pascholati, S.F.; Resende, M.L.V.; Romeiro, R.S. (Eds.). Indução de resistência em plantas a patógenos e insetos. Piracicaba: FEALQ. p. 81-124.

Comissão de Química e Fertilidade do Solo - RS/SC. 2004. Manual de adubação e calagem para os Estados do Rio Grande do Sul e Santa Catarina. 10. Ed. Porto Alegre. $400 \mathrm{p}$.

Faria, G. de S.; Vida, J.B.; Verzignassi, J.R.; Tessmann, D.J.;

Lorenzetti, E.R.; Gasparotto F.

2011. Controle de oídio em pepino parternocárpico com produtos alternativos em cultivo protegido. Summa Phytopathologica, Botucatu, 37(4): 205-207.

Garedew, A.; Schmolz, E.; Lamprecht, I.

2004. Microbiological and calorimetric investigations on the antimicrobial actions of different propolis extracts: an in vitro approach. Thermochimica Acta, 422: 115-124.
Grange, J.M.; Davey, R.W.

1990. Antibacterial properties of propolis. Journal of the Royal Society of Medicine, 83: 159-160.

Ishida, A. K.N.; Bettiol, W.; Souza, R.M.

2001. Controle de oídio (Sphaerotheca fuliginea (Schlecht. et Fr.) Poll.) da abobrinha com extr atos aquosos de matéria orgânica. Ciência Agrotécnica, 25: 1229-1234.

Konstantinidou-Doltsinis, S.; Schmit, A.

1998. Impact of treatment with plant extracts from Reynoutria sachalinensis (F. Schmidt) Nakai on intensity of powdery mildew severity and yield in cucumber under high disease pressure. Crop Protection, 17: 649-656.

Moraes, W.B.; Jesus Junior, W.C. de; Belan, L.L.; Peixoto, L.

de A.; Pereira, A.J.

2011. Aplicação foliar de fungicidas e produtos alternativos reduz a severidade do oídio do tomateiro. Nucleus, 8: 1-12.

Pereira, C.S.; Guimarães, R.J.; Pozza, E.A. \& Silva, A.A. da. 2008. Controle da cercosporiose e da ferrugem do cafeeiro com extrato etanólico de própolis. Revista Ceres, 55: 369-376.

Pozza, A.A.A.; Carvalho, J.G. de; Montanari, M.; Guimarães, P.T.G.; Santos, D.M.

2004. Efeito do silício no controle da cercosporiose em três variedades de cafeeiro. Pesquisa Agropecuária Brasileira, 29: 185-188.

R Development Core Team.

2008. R: A language and environment for statistical computing. R Foundation for Statistical Computing, Vienna, Austria. ISBN 3-900051-07-0, URL http://www.R-project.org.

Shaner, G. \& Finney, R.E.

1977. The effect of nitrogen fertilization on the expression of slow-mildewing resistance in Knox wheat. Phytopathology, 67: 1051-1056.

Stadnik, M.J.

2000. Indução de resistência a oídios. Summa Phytopathologica, 23: 175-177.

Stadnik, M.J.; Kobori, R.F.; Bettiol, W.

2001. Oídios de cucurbitáceas. In: Stadnik, M.J.; Rivera, M. C. Oídios. Embrapa Meio Ambiente, Jaguariúna. p. 217-254.

Stompor-Chrzan, E.

2004. Evaluation of usefulness of propolis for control of damping off on leguminous plants. Progress Plant Protection, 44: 1111-1121.

Vieira, G.H.C. da; Andrade, W.P, da.

2009. Efeito fungicida de produtos alternativos no controle de oídio em pepineiro. Omnia Exatas, 2: 45-49.

Uzel, A.; Sorkun, K.; Onçag, O.; Çogulu, D.; Gençay O.; Salih, B. 2005. Chemical composition and antimicrobial activities of four different Anatolian propolis samples. Microbiological Ressearch, 160: 189-195. 
